\title{
Library Support for Science Research and Education in Leading Liberal Arts Colleges: Survey Results
}

\author{
Alison S. Ricker and Jeffrey A. Witmer
}

In this article the investigators present results of a 1988-89 survey of liberal arts college libraries, focusing on science collections and science library facilities and personnel. The responses from colleges with strong science programs (here referred to as the "research colleges'") are compared with data received from other liberal arts colleges. The research colleges as a group devote more resources to science collections than do the other colleges in the sample. In addition, library-staffed science libraries are found more often at research colleges. The survey helped to improve communication among science librarians in college settings, a process that has been further facilitated by the formation of an ACRL-STS Discussion Group for College Science Librarians.

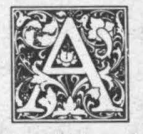

lthough dozens of books and articles that focus on research libraries or specific topics relevant to science libraries have been written in the past two decades, little in the literature documents the current level of college library support for science education and research. ${ }^{1}$ College science librarians and library directors feel this lack most keenly when they face difficult decisions related to facilities planning, acquisitions allocations, staffing patterns, and library automation. With the assistance of a grant from the Council on $\mathrm{Li}$ brary Resources, the authors undertook a survey to determine the depth of library support for the sciences, relative to the number of faculty members and student majors in science disciplines, at liberal arts colleges. $^{2}$

\section{LIBERAL ARTS \\ COLLEGES PRODUCE MANY SCIENTISTS}

The impetus for the survey came partially from two conferences hosted by Oberlin College in 1985 and 1986 on the future of science education at liberal arts colleges. Representatives from fifty colleges participated in the conferences. These institutions, sometimes referred to as "research colleges," had been identified as being on par with the best American research universities at the undergraduate level, based on various criteria of alumni success. Those criteria, as outlined in the report prepared for the 1986 conference, entailed a significant number of alumni having

- earned doctorates in the sciences,

- achieved membership in American Men

Alison S. Ricker is Science Librarian and Jeffrey A. Witmer is Associate Professor of Mathematics at Oberlin College, Oberlin, OH 44074. The authors thank Oberlin College Director of Libraries William A. Moffett for his encouragement, support, and advice throughout the project. They also thank the many Oberlin students who assisted with data tabulation and the dozens of librarians who collectively spent well over one hundred hours answering the questionnaire. Support for this work was partially funded by the Council on Library Resources. 
and Women of Science,

- been listed in Who's Who in Frontier Science and Technology,

- won National Science Foundation Fellowships,

- been among the 1,000 most cited authors in science, and

- been elected to the National Academy of Sciences. ${ }^{3}$

The 1985 report pointed out that these relatively small, independent, and highly selective four-year colleges provide a contrast to national trends in science education. For example, while interest in science has declined among freshmen nationwide, the colleges named in the report continue to enroll freshman classes with very high proportional interest in science, and the percentage of all graduates from these colleges earned degrees in the basic sciences held steady at 24 percent from 1975 through 1983. Authors David Davis-Van Atta, Sam Carrier, and Frank Frankfort state in the report that "these colleges have consistently graduated students in the sciences in much greater proportion than either the nation's colleges and universities as a whole or than those public and private U.S. research universities that are top-rated by the National Academy of Sciences. ${ }^{\prime 4}$

Reports for both conferences focused on what the colleges have been doing to ensure alumni success in science and what steps must be taken to ensure continued success. Libraries were mentioned only briefly, however, primarily in the context of increasing collection size to meet the demands of new faculty. Little consideration was given to the broader role of library for supporting science education and research.

Another impetus for our survey was the meeting of approximately sixty college library directors at Oberlin College in November $1986 .{ }^{5}$ During the last session of the two-day meeting, the directors proposed that a survey of their group be undertaken, primarily to provide comparative data for their internal use.

\section{SURVEY METHODOLOGY}

Questionnaires were mailed to 136 institutions in November 1988. The response rate was high: ninety-six usable responses (70.6 percent) were received by January 1989. The questionnaire was designed to gather data on physical facilities (including automation), collection size, library clientele, personnel, materials budget, building use, service hours, circulation, interlibrary loan, reference and other information services, library instruction, and collection development issues. We based the survey instrument loosely on one developed by the Committee on Comparison of Science and Technology Libraries, a standing committee of ACRL's Science and Technology Section. ${ }^{6}$ A copy of the questionnaire is available upon request. A follow-up query regarding 1988-89 acquisition allocations and the percentage devoted to science collections was mailed in May 1989, since many respondents were not able to provide the detailed expenditure figures we had requested in the original questionnaire.

The survey population included fortynine of the colleges that participated in the Oberlin science conferences, hereafter referred to as Group I, plus a representative group of other private liberal arts colleges, which we designate as Group II. The Group II colleges were all categorized by the Carnegie Foundation as either Liberal Arts I or II, based on the selectivity and stated mission of the institution. ${ }^{7}$ Student enrollments at the surveyed colleges range from 1,000 to 3,500 . We observe that although Group II undoubtedly includes many colleges with excellent science programs, undergraduate participation in those programs is not as high as in the Group I colleges, and graduates from the Group II programs do not undertake graduate study and research or teaching careers in science as frequently as do graduates from the Group I colleges. Fortyseven of the respondents were from Group I institutions and forty-nine were from Group II. ${ }^{8}$ Responding colleges are listed in appendix A.

During January and February of 1989, two student assistants entered the numerical survey data into a Vax $11-780 \mathrm{com}-$ puter. Another student compiled and categorized the narrative comments in June. Over a dozen responses required clarifica- 
tion and verification with the respondents, and final corrections to the data were made in August 1989. We used the statistics program MINITAB in analyzing the data, and a preliminary summary of the numerical data was mailed to each respondent on March 24, 1989. A revised version of that summary is available upon request. The narrative comments have not been distributed to the respondents but are also available upon request (the comments were compiled without attribution to source). Some preliminary comparisons between university and college science libraries were made during a program at the Fifth National Conference of ACRL held in Cincinnati on April 8, $1988 .{ }^{9}$ The program speakers focused on the survey results relating to bibliographic instruction, personnel, materials expenditures, and physical facilities.

\section{RESULTS}

The most striking impression about the survey group as a whole is the variability from campus to campus. For example, the percentage of the library acquisitions budget that is devoted to science materials ranged from 4.4 to 41.9 percent (sixty-one institutions reported allocation figures and are depicted in figure 1). Clearly, library services, collections, and facilities evolve to satisfy local needs.

\section{DECENTRALIZED FACILITIES COMMON}

Unfortunately, the length (eleven pages) and detailed nature of the questionnaire resulted in many scanty responses. All respondents were at least able to indicate where science library ma- terials are housed: eighty colleges (83 percent) integrate science materials within their main library, while fifty-six respondents ( 58 percent) indicated that science materials were in branch libraries. The total of these two responses is greater than ninety-six (the total number of usable questionnaires returned) because most colleges with branch or departmental science libraries also shelve some science materials in their main libraries.

Sixteen of the colleges maintain more than one science branch library: eightynine branch libraries were described by the respondents as a whole. Fifty-six of these are single-discipline collections, while twenty-three of the branch libraries house the materials of four or more disciplines. Nearly all $(n=85)$ of the branch libraries are located in buildings that also house academic departments, while four are in separate buildings designed solely or primarily for the purpose of housing the science library.

The size of branch libraries varies greatly, from small departmental collections that offer seating for fewer than ten users to multidiscipline science libraries over 10,000 square feet in size and with seating for 250 or more users. The typical science library on a college campus may be best exemplified by those at Carleton, Clark, Haverford, Oberlin, and St. Olaf: square footage of these libraries ranged from 4,500 to 6,200 , seating capacity ranged from fifty-eight to 110 , and the libraries were designated as the primary location for the materials of three or more basic science disciplines. Larger science libraries are found at Colgate, Earlham, Holy Cross, Knox, Smith, Swarthmore,

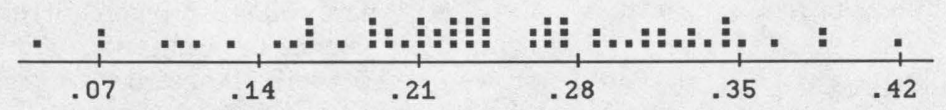

Each dot represents the percentage of the library acquisitions budget allocated to science materials at one institution. Note that the largest value is .419 , which means that one college allocated $41.9 \%$ of its library acquisitions budget to science. Many figures are based on estimates, as not all respondents allocate along disciplinary or departmental lines.

FIGURE 1

Percentage of the Total Acquisitions Budget Allocated to Science Library Materials 
"Integrated science libraries, staffed by a professional librarian, do not represent the norm on college campuses."

Wellesley, and Wesleyan. A new science library now under construction at Franklin and Marshall will be one of the largest facilities in the survey group.

\section{UNSTAFFED DEPARTMENTAL LIBRARIES LACK SERVICES}

Integrated science libraries such as these, staffed by a professional librarian, are more likely to be found at Group I colleges (see appendix B) but do not represent the norm on college campuses, at either Group I or Group II institutions. A more prevalent arrangement is the unstaffed departmental library, containing at least a modest reference collection, current journals, and usually the major indexing tool for a single discipline. Most of these collections are theoretically under the jurisdiction of the college librarian, but the narrative comments provide insight in how these collections are actually managed (or left unmanaged, as the case may be). The following are comments from several respondents:

No circulation statistics are kept for the science library, because, presumably, nothing circulates. Faculty offices are, however, full.

The science libraries can be more accurately described as reading rooms. Although they contain both library-owned and departmentalowned materials, no library service ... is provided.

Separate satellite libraries for the various science departments have existed over the years . . . these are basically reading rooms . . . unsupervised . . . no library security systems.

The science branches are not staffed. The science departments are now discussing the need for more space and as a part of that discussion they are considering the desirability, feasibility, etc., of a combined science library.

There is only minimal structure in [our] branch libraries, and none in two of them. We are planning an expansion of the main library which will combine the science collections in an identifiable location within the main library and plan to hire a science librarian.

The branch was absorbed [into the main library] because we never had a science librarian ... [it] was primarily student staffed, thus, there was no reference assistance for [indexing] tools. The science faculty, of course, will never forgive us for closing their branch library.

This last comment reflects the statements of several other respondents. Science faculty are generally very much in favor of retaining departmental or branch libraries where they exist, and they often propose that such collections be established. In addition, science faculty may think that the supervision of those collections by a professional librarian is of less importance than the proximity of the collection. Science faculty are commonly given unlimited access to unstaffed branch collections. Certain groups of students are also granted that privilege at many of the responding colleges. Inevitably, security problems are a nagging worry for librarians at those institutions.

Chemistry materials are most likely to be found in a branch library (fifty-two respondents gave this reply), followed by biology and physics (thirty-six and thirtyfive respondents, respectively). Chemistry department staff are also most likely to be involved in the management or supervision of branch libraries, and often take responsibility for teaching students how to search the chemical literature. Narrative comments indicate that science faculty as a whole are often willing to take an active part in teaching students to use reference sources.

\section{SCIENCE LIBRARIANS EMPLOYED BY 30 PERCENT OF SCHOOLS}

Twenty-nine colleges ( 30 percent) either employed science librarians at the time of the survey or were in the process of hiring a person to fill a temporarily vacant science librarian position. Nine of the science librarians described by the respondents are actually located in the main library, either because the campus does not have science libraries or because the small departmental collections that do exist are not 
supervised directly by the science librarian. A list of colleges with science libraries that are staffed by a professional science librarian is given in appendix B. "Professional" was defined on the survey as a position requiring the M.L.S. degree or its equivalent.

A professional science librarian reportedly supervised the science library or libraries at twenty colleges; other library staff managed science branch libraries at seventeen colleges, while twenty-three respondents said nonlibrary staff managed the science branch library(ies) on campus (appendix C). The total number of managers or supervisors of science branch libraries is greater than fifty-six (the total number of colleges that have one or more branch libraries) because several colleges reported more than one person with branch library responsibilities.

Most of the colleges that employ a science librarian who is located in the college's science library belong to Group I. This may be an indication of greater support given overall to science education and research at these institutions and a willingness on the part of faculty, library staff, and college administrators to conclude that professionally staffed science libraries are vital to the science program.

Conversely, Group II institutions are more likely to have science branch libraries that are supervised by nonlibrary personnel and are also more likely to maintain dispersed, unstaffed departmental libraries rather than a science library that includes collections for several disciplines. Several library directors indicated in their narrative comments the belief that service for the science clientele could be improved. Some respondents implied that bibliographic instruction, collection development, and reference services for science faculty and students could be better coordinated by one member of the library professional staff with subject expertise in science.

Student staff are relied upon more heavily in science libraries than in main libraries, at least in terms of staffing circulation desks when full-time library staff are unavailable. College science libraries are staffed, on average, forty hours per week by student assistants alone. The corresponding average for main libraries is fifteen hours per week of unsupervised student staff. These numbers were calculated only for those libraries that maintain regular hours and are not accessible to the general public when library staff are unavailable.

\section{MANY SCIENCE LIBRARIANS LACK SCIENCE DEGREE}

It is often assumed that an effective science librarian should have an academic background in a traditional science field. ${ }^{10}$ Science librarian job postings frequently cite a bachelor's degree in biology, chemistry, physics, or an allied discipline as either a requirement or a desired qualification. A position that entails collection development for the sciences may require graduate work in a science discipline. Fewer than half of the science librarians described by the respondents, however, had a subject degree in the sciences (twelve out of twenty-seven, or 44 percent). This is remarkably similar to Joy Thomas' findings on the subject backgrounds of California academic science librarians with bibliographic instruction responsibilities (forty-three of the ninetyeight academic librarians in her survey had a bachelor's, master's, or doctoral degree in a scientific or technical discipline). ${ }^{11}$ We did find, however, that if the science librarian held an advanced subject degree, it was likely to be in science. A few respondents noted that while their major area of study had not been in the physical or life sciences, they had taken a variety of introductory-level courses that were relevant (including philosophy and history of science) and that had proven useful over the years.

\section{BIBLIOGRAPHIC INSTRUCTION FOR SCIENCE STUDENTS}

The number of students present at all bibliographic instruction (BI) sessions for science classes per college varied from five to 625 during 1987-88, with a median of 79.5 and a mean of $128(n=60)$. The number of students at science BI sessions at colleges with a science librarian ranged from twenty-five to 625 , with a median of 
112 , compared to a range of five to 336 students and a median of sixty-three at those colleges without a science librarian. Figure 2 subdivides these data to compare Group I to Group II institutions. Of the ten colleges where more than 250 students received science-related BI, eight are part of Group I, and seven employed a science librarian at the time of the survey.

Since we know of only twenty-nine science librarians in the entire survey sample, it seems likely that many colleges are relying upon other members of the library staff (or teaching faculty) to teach science students how to use the library. Even when science librarians are available, the number of students who receive formal course-related instruction is sometimes very low. Employing a science librarian, while not ensuring an active science BI program, may result in reaching more students in course-related instruction. Obviously, other factors are also important: enthusiasm and support for library instruction on the part of library staff, teaching faculty, and the library administration are often just as crucial as hiring someone to do the job.

\section{ACQUISITIONS BUDGET ALLOCATIONS TO SCIENCE}

Roughly one third of the respondents said they do not monitor expenditures or allocations for individual disciplines. Expenditures for fiscal year 1987-88 varied widely, whether comparing different departments at the same institution or the same discipline at different institutions. For example, the number of dollars spent on books and serials combined per faculty member in biology varied from $\$ 460$ to $\$ 14,619$. These figures appear in table 1 , along with expenditures per faculty member in chemistry, mathematics, and physics.

The 1988-89 allocation for all science materials was reported by fifty-seven institutions and ranged from $\$ 5,000$ to $\$ 380,475$. As noted earlier, the percent of the acquisitions budget allocated to science varied from 4.4 percent to 41.9 percent with 24 percent as the overall average. The median percentage for Group I is 27.9 percent, slightly higher than the me- dian for Group II (20.9 percent). The lowest percentage for science materials allocation reported by a Group I college was 19.2 percent, while the highest percentage for a Group II institution was the highest reported overall, 41.9 percent.

Library support for the sciences, at least in terms of relative proportion of the acquisitions budget, is thus shown to be quite significant for some Group II colleges. This budgetary commitment is made despite the relatively low numbers overall of science faculty or students enrolled in science at Group II colleges.

"Science faculty are generally very
much in favor of retaining depart-
mental or branch libraries where they
exist and often propose that such col-
lections be established."

Interesting differences became apparent when we compared those institutions with science libraries or science librarians to those that have neither. For example, colleges in the former category tend to spend more money, per faculty member, for science acquisitions than do colleges in the latter category (figures 3 and 4). This finding is not startling because the presence of a science library or science librarian should indicate that the institution places a high priority on science education and is willing to invest the money and personnel necessary to support the sciences with specialized library service. The presence of a science library (or science librarian) may also indicate that the science faculty are more library and research oriented and more likely to request materials for the collection than are faculty at other colleges.

\section{JOURNALS' PORTION OF COLLECTION AND BUDGET}

Information about the science collection itself is somewhat sketchy, particularly because not all libraries with branch facilities maintain separate statistics for individual collections. The median number of 


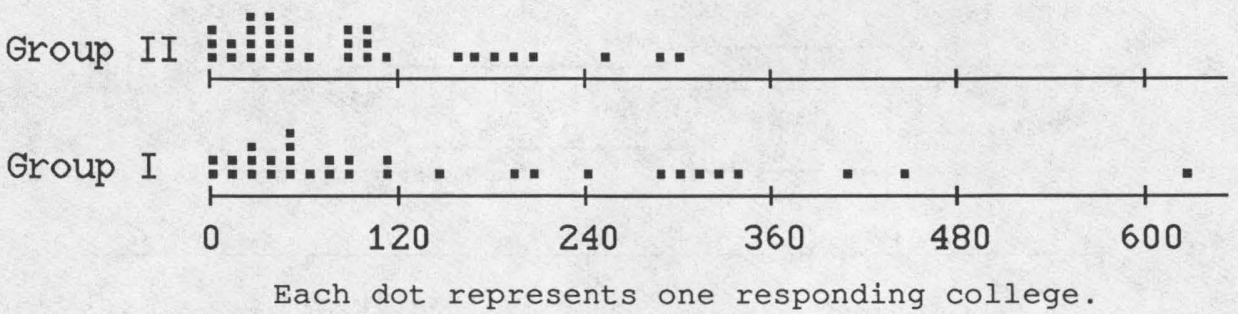

FIGURE 2

Comparison of Students Present at BI Sessions for Science Classes by Group I or Group II

0

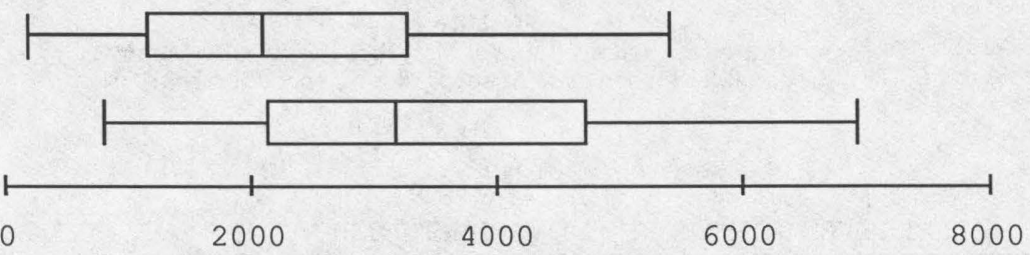

The bottom line indicates budget allocations for science library materials in U.S. dollars. The top group (0) represents colleges without science libraries; the bottom group (1) represents colleges with one or more science branch libraries.

NOTE: For each group in Figures 3 and 4, the box extends from the first quartile of the distribution to the third quartile, with the vertical line within the box indicating the median. Lines extend down to the minimum and up to the maximum. For example, for colleges with a science library (group 1 above) The minumum budget allocation per faculty member for science library materials was $\$ 800$, the first quartile was $\$ 2,100$, the median was $\$ 3,200$, the third quartile was $\$ 4,800$, and the maximum was $\$ 7,000$.

\section{FIGURE 3}

Expenditures for Science Library Materials Per Faculty Member. Variable: Presence or Absence of a Science Library

current science serial subscriptions for the entire sample was $228(\mathrm{n}=65$, range $=$ 13-812). More than half of the respondents make a substantial commitment to providing journal collection access in the form of print or CD-ROM subscriptions and/or online access to major indexing tools. The General Science Index was received by eighty libraries; Chemical $A b$ stracts and Biological Abstracts were received by seventy-nine and seventy-eight respondents, respectively; followed in popularity by Index Medicus ( $\mathrm{n}=63$ ), Mathematical Reviews ( $\mathrm{n}=61)$, Physics $A b$ stracts $(\mathrm{n}=56)$, and Science Citation Index $(n=42)$. Over eighty additional indexing titles were currently received by one or more of the respondents. Many of these indexes reflected highly specialized fields of scientific, technical, and health-related research.

Not surprisingly, expenditures for science serials were significantly higher than those reported for science monographs (with the exception of materials for computer science). For example, the average amount spent on biology subscriptions was five times that spent on biology monographs, a ratio repeated with slightly less magnitude for chemistry, physics, and geology. Despite fewer users and, in most college settings, an absence 
0

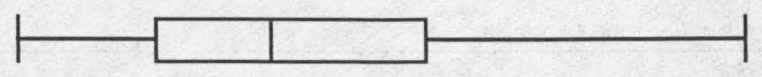

1
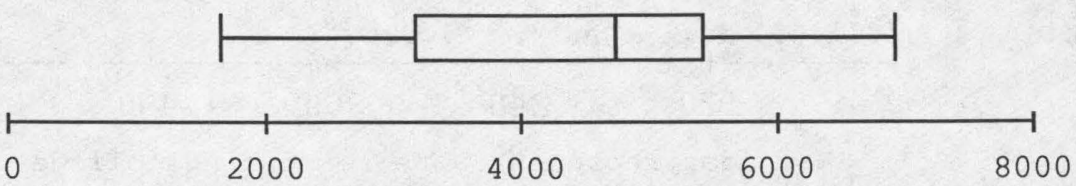

The bottom line indicates budget allocations for science library materials in U.S. dollars. The top group (0) represents colleges without a science librarian; the bottom group (1) represents colleges that do employ a science librarian (position titles vary).

FIGURE 4

Expenditures for Science Library Materials Per Faculty Member. Variable: Presence or Absence of a Science Librarian

TABLE 1

DOLLARS SPENT ON BOOKS AND SERIALS COMBINED PER FACULTY MEMBER

\begin{tabular}{lcccr}
\hline \hline Department & $\begin{array}{c}\text { Number of } \\
\text { Respondents }\end{array}$ & Minimum $(\$)$ & Median $(\$)$ & Maximum (\$) \\
\hline Biology & 63 & $\$ 460$ & $\$ 3,249$ & $\$ 14,619$ \\
Chemistry & 62 & 329 & 2,906 & 9,026 \\
Mathematics & 63 & 92 & 1,896 & 4,505 \\
Physics & 57 & 240 & 2,775 & 10,764 \\
\hline
\end{tabular}

of graduate students, patterns of college library science expenditures are similar to those of larger research libraries; reliance upon journals to support scientific research seems to be universal.

We also found that several variables related to collection development are significantly more highly correlated with the number of faculty than with the number of declared majors in the sciences at an institution. For example, the number of current science journal subscriptions is more highly correlated with total science faculty $(\mathrm{r}=.656)$ than with total science majors $(r=.232)$. Similarly, the number of science monographs added per year is more closely related to the number of science faculty $(r=.537)$ than the number of science majors $(r=.100)$, and total combined expenditures for materials in mathematics, physics, chemistry, and biology is more highly correlated with total number of faculty in those disciplines $(r=.677)$ than the number of declared majors in those disciplines $(r=.133)$. These find- ings reflect the faculty-driven nature of collection development in the sciences at many colleges. Only two respondents indicated that a science librarian has the primary responsibility for selecting science materials for the library; fifty-eight respondents said that faculty and librarians shared that responsibility, while thirtynine said that science faculty had the primary responsibility for materials selection.

Many respondents commented that print versions of journal indexes were being cancelled in favor of online or CDROM access (different philosophies were revealed by those cancellations: some libraries cancelled the cumulative indexes for Biological Abstracts and Chemical Abstracts but retained subscriptions to the abstracts, while other libraries did exactly the opposite). Dialog was the service available for online searching at most libraries $(n=88)$, followed by BRS $(n=47)$ and STN $(n=25)$. CD-ROM products were more prevalant than we anticipated 
( $N=29$ ), based on surveys conducted of ARL institutions in earlier years, indicating that the technology is becoming more accessible.

\section{COLLECTIONS OF OTHER INSTITUTIONS RELIED UPON}

We asked respondents to indicate to what extent selection decisions are influenced by holdings in neighboring libraries for monographs and periodicals. Fiftyfour respondents said "not at all" for monographs, while seventy-four said "somewhat" or "very much" for periodicals. Special arrangements exist on many campuses that facilitate the use of neighboring collections by college faculty and students. In-person borrowing privileges for faculty and students of nearby colleges are granted by many university libraries.

\section{"While fewer than half of the science librarians had a subject degree in the sciences, if they held an advanced subject degree, it was likely to be in science."}

Interlibrary loans are often expedited by telefacsimile transmission and/or special courier service. Some hospitals and private research facilities open their collections to college users, either informally or through formal reciprocal arrangements, and other area colleges may provide resources as well. Much cooperation is evident among the responding libraries and their neighbors, from cost-sharing of journal subscriptions to, in one case, sharing a science librarian.

\section{CONCLUSION}

The survey results contain more data than can be adequately summarized here. In addition, our information reflects a very brief period in time that does not capture the climate of change revealed in the nar- rative comments. Many of the responding colleges plan to upgrade or create science library facilities, hire new personnel, change allocation patterns, install automated circulation or catalog systems, contract with suppliers of databases of one kind or another, or initiate new user services. A repeat survey would document these changes and provide a basis for observing trends. The ACRL-STS Committee on Comparison of Science and Technology Libraries has made a commitment to repeat its survey of research libraries on a biannual basis, "if interest in participation and results is sustained." 12 It would be useful to solicit data from college libraries on a regular basis as well and compare the data from the two groups.

This project grew out of a realization that science library facilities at research colleges are receiving more attention from library directors, administrators, and faculty than in the recent past. Our supposition that single-discipline, departmental collections are not adequate to meet the demands of students and faculty for scientific information was confirmed by many respondents in their narrative comments and in personal communications. Improved service, from both technical and public services staff, can be achieved when these often haphazardly maintained, decentralized facilities are consolidated and brought under the management of a professional science librarian. Evan Farber makes this argument in his essay "Science Libraries in Colleges." 13 We found that improved service has also been achieved when consolidation of departmental libraries meant bringing science materials to the main library or to a separate wing of the main library. A key component of such a plan is assigning a qualified member of the professional library staff the responsibility for coordinating collection development and services for science users. We judge that the "science-active" colleges in our survey are more inclined and capable of making that commitment. 


\section{REFERENCES AND NOTES}

1. See, for example, Ellis Mount, ed., One Hundred Years of Sci-Tech Libraries (New York: Haworth, 1988), also published as Science and Technology Libraries 8 (Fall 1987); Robert A. Seal, "Academic Branch Libraries," in Advances in Librarianship, ed. Wesley Simonton (Orlando: Academic Press, 1986), p.175-209. Seal's article gives a fine review of the literature, including many early publications on the question of centralization or decentralization of collections. He concludes with the observation that there may be a trend in academic libraries to consolidate departmental libraries, rather than creating new branch locations, but calls for further study to supplement recent surveys of ARL institutions.

2. Council on Library Resources, Washington, D.C., Grant no. CLR 4048-E, January-June 1989.

3. Sam Carrier and David Davis-Van Atta, Maintaining America's Scientific Productivity: the Necessity of the Liberal Arts Colleges (Oberlin, Ohio: Oberlin College Office of the Provost and Institutional Research, 1987).

4. David Davis-Van Atta, Sam C. Carrier, and Frank Frankfort, Educating America's Scientists: the Role of the Research Colleges (Oberlin, Ohio: Oberlin College Office of the Provost, 1985), p.10.

5. A meeting of the Oberlin Group is reported in College \& Research Libraries News 50:981-82 (Dec. 1989).

6. Emerson Hilker, Head of the Physical Sciences and Engineering Division, Oklahoma State University Library, provided a copy of the questionnaire. The results of the 1984-85 survey are summarized by Hilker in "Statistical Data for Stand-alone Science/Engineering Libraries in the United States and Canada 1984-85," Science and Technology Libraries 8:89-127 (Fall 1987). Hilker reports on the 1986-87 survey in "Survey of Academic Science/Technology Libraries," College \& Research Libraries News 49:375-76 (June 1988).

7. The Carnegie Foundation for the Advancement of Teaching, A Classification of Institutions of Higher Education, 1987 ed., (Princeton, N.J.: The Foundation, 1987). Liberal Arts I and II colleges are primarily undergraduate institutions that award more than half of their baccalaureate degrees in arts and sciences fields. An index developed by Alexander W. Astin at the University of California at Los Angeles was used by the foundation to determine the selectivity of liberal arts colleges.

8. After consultation with the respondent, an additional Group II college was dropped from the sample because the response had been limited to library services on a specialized campus for energy technology education.

9. An abstract of the conference program appears as "Library Support of the Sciences in Liberal Arts Colleges," in Building on the First Century: Proceedings of the Fifth National Conference of the Association of College and Research Libraries, Cincinnati, Ohio, April 5-8, 1989, ed. Janice C. Fennell (Chicago: ACRL, 1989), p. 346. Panel members were Alison Ricker; Jeffrey Witmer; Kimberly Douglas, head of Reader Services, California Institute of Technology Millikan Library; and Sara Penhale, science librarian, Earlham College. Comparisons between university and college libraries were made by Ms. Douglas, who is a member of the ACRL-STS Committee on Comparison of Science and Technology Libraries. Her observations included the obvious differences in size (science libraries at universities are far larger, in terms of square feet, reader spaces, number of volumes, number of current journal subscriptions, etc.), in the breadth and depth of the collections, the diversity and number of clientele served, and overall expenditures, to name but a few areas. Ms. Douglas made the interesting observation that although overall expenditures in a college library are significantly lower than in a university library, journal subscription costs per faculty member are much higher in the college library group as a whole than in the university library group.

10. Recent papers that touch on this issue include Lorene B. Brown, "Recruiting Science Librarians," in Librarians for the New Millennium, ed. ALA Office for Library Personnel Resources, (Chicago: American Library Assn., 1988), p.65-71; Linda C. Smith, "Education for Sci-Tech Librarianship: Retrospect and Prospect," Science and Technology Libraries 8:75-88 (Fall 1987); Joy Thomas, "Bibliographic Instructors in the Sciences: A Profile," College \& Research Libraries 49:252-62 (May 1988).

11. Thomas, "Bibliographic Instructors," p.253.

12. Hilker, "Survey," p.375.

13. Evan I. Farber, "'Science Libraries in Colleges," Library Issues: Briefings for Faculty and Administrators 7:3 (July 1987). 


\section{APPENDIX A. COLLEGES THAT RESPONDED TO THE “SURVEY OF LIBRARIES IN FOUR-YEAR LIBERAL ARTS COLLEGES WITH RESPECT TO SCIENCE COLLECTIONS," NOVEMBER 1988}

Adrian College, Mich. Albion College, Mich.* Albright College, $\mathrm{Pa}$. Alma College, Mich.* Amherst College, Mass.* Antioch College, Ohio* Augustana College, Ill. Austin College, Tex. Barnard College, N.Y.* Bates College, Maine* Beloit College, Wisc. * Berea College, Ky. Bowdoin College, Maine* Bryn Mawr College, Pa. * Bucknell University, Pa. * Carleton College, Minn. * Clark University, Mass. Colby College, Maine Colgate University, N.Y.* Colorado College, Colo.* Columbia College, S.C. University of Dallas, Tex. Davidson College, N.C.* Denison University, Ohio* DePauw University, Ind. * Drew University, N.J. Earlham College, Ind. * Eckerd College, Fla.

Franklin and Marshall College, Pa. *

Furman University, S.C.

Goshen College, Ind.

Grinnell College, Iowa*

Guilford College, N.C.

Gustavus Adolphus College, Minn.

Hamilton College, N.Y.*

Hampshire College, Mass.

Hartwick College, N.Y.

Haverford College, $\mathrm{Pa}$.

Hiram College, Ohio

College of the Holy Cross, Mass. *

Houghton College, N.Y.

Immaculata College, $\mathrm{Pa}$.

Jordan College, Mich.

Kalamazoo College, Mich.*

Kenyon College, Ohio*

Knox College, Ill.

Lafayette College, $\mathrm{Pa}$.

Lake Forest College, Ill.

Lawrence University, Wisc.
Luther College, Iowa

Macalester College, Minn.*

Manhattan College, N.Y.*

Manhattanville College, N.Y.

Middlebury College, Vt. *

Mills College, Calif.

Mount Holyoke College, Mass. *

College of Notre Dame, Calif.

Oberlin College, Ohio*

Occidental College, Calif.*

Ohio Wesleyan University, Ohio*

Pomona College, Calif. *

Randolph-Macon College, Va.

Reed College, Oreg.*

Regis College, Mass.

Saint John's University, Minn.

Saint Joseph's College, Brooklyn, N.Y.

Saint Joseph's College, Patchogue, N.Y.

Saint Lawrence University, N.Y.

Saint Olaf College, Minn.*

Sarah Lawrence College, N.Y.

Simmons College, Mass.

Skidmore College, N.Y.

Smith College, Mass. ${ }^{*}$

Spring Hill College, Ala.

Swarthmore College, $\mathrm{Pa}$. ${ }^{*}$

Trinity College, Conn.*

Trinity University, Tex.

Union College, N.Y.*

University of The South, Tenn.

Ursinus College, Pa.

Vassar College, N.Y.*

Wabash College, Ind.

Warburg College, Iowa

Washington and Jefferson College, $\mathrm{Pa}$.

Washington and Lee University, Va.

Wellesley College, Mass.*

Wesleyan University, Conn. *

Western Maryland College, Md.

Wheaton College, Ill.*

Wheaton University, Mass.

Whitman College, Wash.*

Whittier College, Calif.

Willamette University, Oreg.

Williams College, Mass.*

Wittenberg University, Ohio

Wofford College, S.C.

College of Wooster, Ohio*

*Indicates that the college is part of Group I (i.e., one of the fifty colleges participating in the Second National Conference on "The Future of Science at Liberal Arts Colleges," Oberlin College, Oberlin, Ohio, June 9-10, 1986). 


\section{APPENDIX B. COLLEGES WITH SCIENCE LIBRARIES THAT WERE STAFFED BY A PROFESSIONAL SCIENCE LIBRARIAN AT THE TIME OF THE SURVEY}

\author{
Bryn Mawr College* \\ Carleton College* \\ Clark University \\ Colby College \\ Colgate University* \\ DePauw University* \\ Earlham College* \\ Grinnell College* \\ Hamilton College* \\ Haverford College*
}

\author{
College of the Holy Cross* \\ Manhattan College* \\ Pomona College* \\ Oberlin College* $^{*}$ \\ St. Olaf College* \\ Swarthmore College* \\ Wellesley College* \\ Wesleyan University* \\ Williams College* \\ Wittenberg University
}

* Group I institution

Colleges in the process of hiring a science librarian or planning to create a science librarian position included Bowdoin, Franklin and Marshall, Manhattanville, Mt. Holyoke, Reed, and Smith. Five of these colleges are Group I institutions.

\section{APPENDIX C. POSITION TITLES OF SCIENCE BRANCH LIBRARY MANAGERS OR SUPERVISORS*}

Library staff positions:

Number in Survey

Assistant librarian

$\begin{array}{r}2 \\ 2 \\ 1 \\ 2 \\ 2 \\ 1 \\ 1 \\ 1 \\ 1 \\ 1 \\ 1 \\ 2 \\ \hline 17\end{array}$

Branch manager

Circulation staff

Clerk or secretary of the science library

College librarian

Documents/reference librarian

Head of circulation

Head of public services

Head of technical services

Library assistant

Periodicals librarian

Reference librarian

Total

Staff provided by other departments:

Biology department faculty

Chemistry department faculty

Chemistry department chair

Chemistry department student assistants

Physics department lab assistant

Secretary (of various academic departments)

Total

*Other than a science librarian with M.L.S. or equivalent. 


\section{TheWilson Indexes on Magnetic Tape!

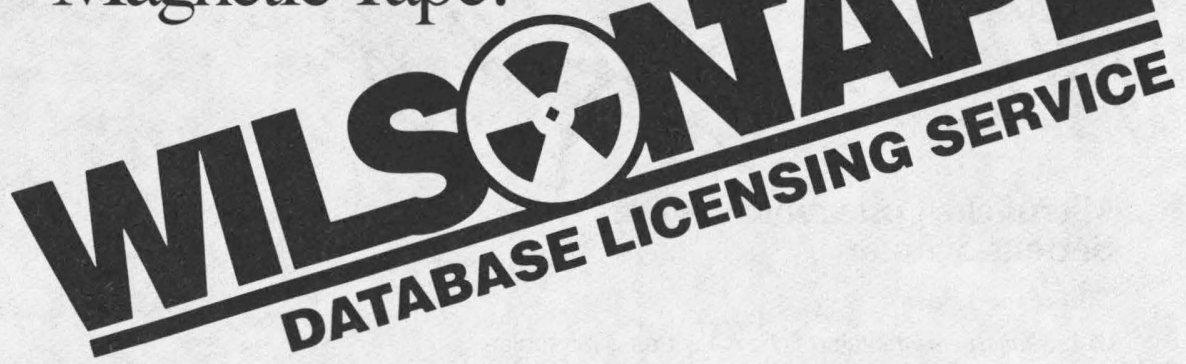

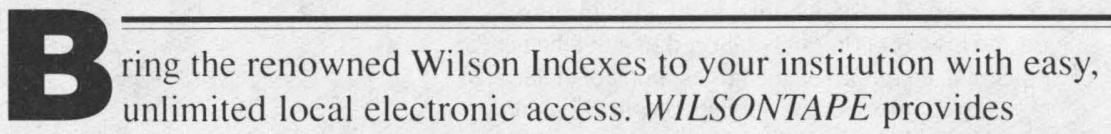

machine-readable monthly tapes for each Wilson database in a uniform format that makes the data accessible with the same system of commands and protocols as your online catalog.

\section{Create a Customized Databank}

WILSONTAPE:

- Maximizes the use of existing hardware and software and of periodical and book holdings

- Promotes simultaneous use by multiple searchers on a round-the-clock basis

- Supports a uniform set of protocols

- Allows unlimited off-site access to centralized reference holdings

- Saves substantial connecttime charges

- Simplifies billing with a single annual subscription rate.

\section{T H E II , || , || I L S O W}

Integrate WILSONTAPE with Your Library Automation System

Call for details.

Call Toll-Free 1-800-367-6770,

Ext. 758 , for an individualized price quotation or for more information about WILSONTAPE.

In New York State call

1-800-462-6060;

in Canada call collect

1-212-588-8400.

Telefax 1-212-590-1617

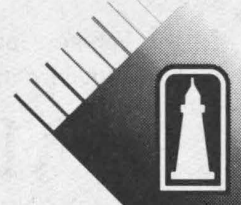

( 0 II P INY

950 U N I V E R I T Y A V E N UE, BR O N X, N Y 10452 


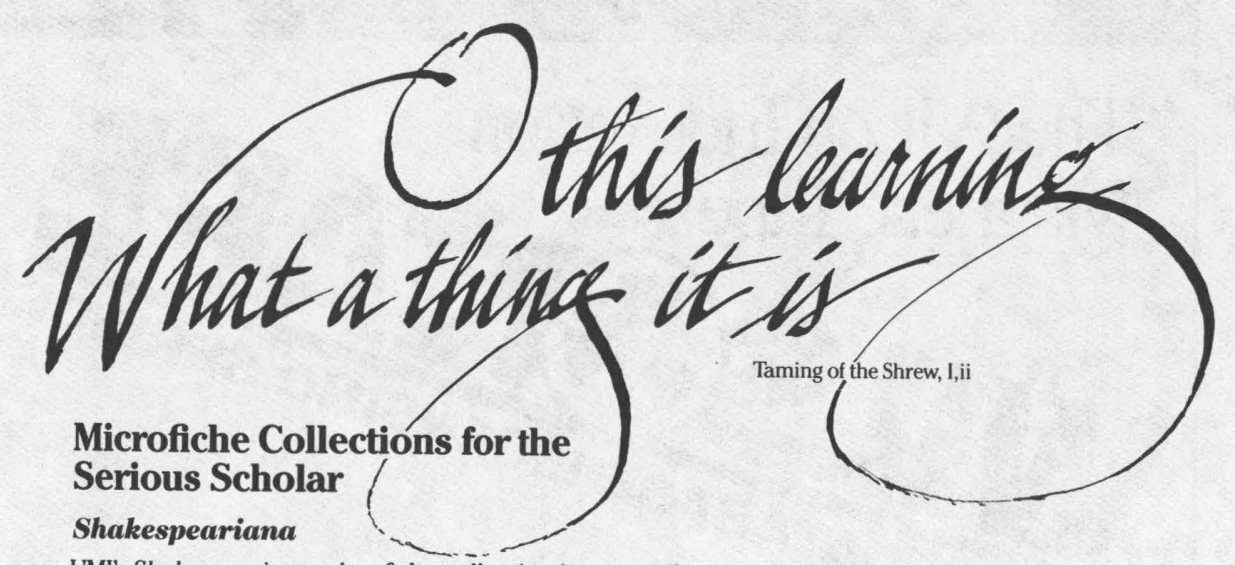

UMI's Shakespeariana microfiche collection is a compilation of four centuries of documents on William Shakespeare and his work. Uniquely tailored to meet the needs of the scholar, it comprises the largest body of material ever assembled into a single published collection, totalling over one million pages, organized into thirty carefully structured units. Included is research material on Shakespearian literature and scholarship as well as the institutions and outside influences which shaped the Elizabethan world view.

The thirty units of Shakespeariana cover a variety of aspects and include facts and fictions about William Shakespeare; institutions, trade, commerce and educational practices of the day; early texts of poems and sonnets; literature which influenced Shakespeare's writing; Shakespearian theater; criticism; biographical data; and Shakespeare's editors.

\section{Other Collections}

For Literature, Drama \& Linguistics Scholars

Concordances to the Novels of Virginia Woolf

The Complete Works of Genevieve Taggard

Source Materials in the Field of Theatre

British \& Continental Rhetoric \& Elocution

The Linguistic Atlas of the Gulf States

The Scrapbooks of Erskine Caldwell The Life \& Work of Henry Irving

Renaissance Rhetoric

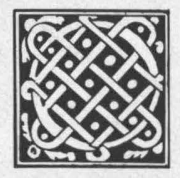

For more information on our literature collections, contact your librarian or call UMI Research Collections.

\section{U.M.I Research}

A Bell \& Howell Company 300 North Zeeb Road, Ann Arbor, Ml 48106-1346 USA Continental US: 1-800-521-0600 